\title{
Morphological characteristics, formation and glaciological significance of Rogen moraine in northern Scotland
}

\author{
Andrew G. Finlayson* and Tom Bradwell
}

British Geological Survey, Murchison House, West Mains Road, Edinburgh, EH9 $3 L A, U K$

* Corresponding author. E-mail: afin@bgs.ac.uk.

\begin{abstract}
Rogen moraine are enigmatic landforms whose exact origin is still debated. We use NEXTMap digital surface models and aerial photographs to map the distribution of previously unreported fields of Rogen moraine in the vicinity of Loch Shin, northern Scotland. Existing models of formation are tested against detailed morphological Rogen moraine characteristics obtained from the remote sensing data and field observations. Detailed morphometric analyses combined with their geographical setting lead us to postulate a likely mechanism of formation. Rogen moraine appear to have formed in areas where there were strong basal ice-flow velocity gradients. Thrusting by compression, or fracturing by extension of preexisting partially frozen sediment probably occurred in these areas, resulting in Rogen moraine formation. A general down-ice increase in ridge crest spacing suggests that the latter process may have been dominant, and is consistent with the location of Rogen moraine in the lee of topographic obstructions, in areas that experienced overall extensional ice flow. We also suggest that at least one field of Rogen moraine formed where lateral basal ice-flow velocity gradients were strongest - possibly in a subglacial shear margin setting. Given their location, the landforms may be consistent with formation during headward scavenging of the Moray Firth palaeo-ice stream into a shrinking core of cold-based ice.
\end{abstract}

Keywords: digital surface models; transverse ridges; ice-flow velocity; ice stream 


\section{Introduction}

Rogen moraine form a landscape of curved to sinuous ridges at approximately right angles to ice movement. Their formation has been linked to a range of ice-sheet behaviour, including thawing beds (Hättestrand, 1997; Hättestrand and Kleman, 1999), freezing beds (Sollid and Sørbil, 1994), ice-stream onset (Dyke et al., 1992), ice-stream shutdown (Stokes et al., 2006), $90^{\circ}$ changes in ice-flow direction (Boulton, 1987), and subglacial outburst floods (Fisher and Shaw, 1992; Shaw, 2002). As a result, the exact genesis of these landforms remains open to debate. Rogen moraine are typically, though not exclusively, found in core areas of former ice sheets. Individual ridges are shown to vary in internal composition and include disaggregated bedrock, subglacial till, and stratified sand and gravel (Hättestrand, 1997). A characteristic feature of classic Rogen moraine is the transformation into, or superimposition of, fluted or drumlinoid forms (Lundqvist, 1989, 1997). Where such features are absent, the North American term ribbed moraine (Hughes, 1964) is used in the literature to describe the ridges. Early researchers considered Rogen moraine formation to take place in an icemarginal environment (Frödin, 1925; Cowan, 1968); however, observation of superimposed eskers and drumlins led other workers to favour a subglacial origin (e.g., Lundqvist, 1969). Since the late 1970s, four main mechanisms for Rogen moraine formation have been proposed: (i) cavity infilling of megaripples eroded into basal ice during subglacial outburst floods (Fisher and Shaw, 1992; Shaw, 2002); (ii) remoulding of preexisting landforms such as ice marginal moraines (Möller, 2006), or drumlins and flutes following a $\sim 90^{\circ}$ change in iceflow direction under deforming bed conditions (Boulton, 1987); (iii) shearing and stacking or folding of debris-rich basal ice or preexisting sediments during compressive ice flow (Shaw, 1979; Aylsworth and Shilts, 1989; Bouchard, 1989; Lindén et al., 2008); and (iv) fracturing and extension of sediment sheets during a transition from cold- to warm-based ice conditions (Lundqvist, 1969; Hättestrand, 1997; Hättestrand and Kleman, 1999; Sarla, 2006). This range of hypotheses currently restricts confidence in palaeoglaciological reconstructions based on any one mechanism of formation (e.g., Kleman and Hättestrand, 1999). Based on unimodal distributions of ribbed moraine characteristics for over 33,000 ridges, Dunlop and Clark (2006) suggest a single formation mechanism may exist. However, Lindén et al. (2008) argue that the landforms are probably polygenetic. The wide range in morphological characteristics presented by Dunlop and Clark (2006) suggests differing processes may have operated in their formation, highlighting the need for detailed, location-specific data on these landforms in areas where they are developed. 
To date, Rogen moraine have been described from North America (e.g., Hughes, 1964; Aylsworth and Shilts, 1989; Bouchard, 1989; Fisher and Shaw, 1992; Stokes et al., 2006), Fennoscandia (e.g., Lundqvist, 1969, 1989, 1997; Hättestrand, 1997; Raunholm et al., 2003; Möller, 2006), and Ireland (e.g., Knight and McCabe, 1997; Clarke and Meehan, 2001), while only sparse accounts exist of the landforms in Britain (e.g., Golledge and Merritt, 2005; Golledge, 2006; Bradwell et al., 2008). This paper presents clear examples of Rogen moraine from the Loch Shin area in northern Scotland (Fig. 1) - the first to be described in detail from Britain. Landform characteristics are presented to assess current hypotheses of formation and to explore implications for ice-sheet conditions during the latter stages of the Main Late Devensian glaciation in northern Scotland.

\section{Study area and glaciological context}

The region around Loch Shin in northern Scotland forms a relatively low-lying area to the SE of the mountainous terrain of Assynt (Fig. 1). A number of wide, shallow valleys trend in a SE direction, draining toward the Dornoch Firth. The local bedrock chiefly comprises Neoproterozoic psammites and semipelites belonging to the Moine Supergroup. Using highlevel weathering limits, Ballantyne et al. (1998) suggested that the ice-sheet surface at the Last Glacial Maximum (LGM) lay between 750 - 800 m over Assynt, with an ice divide lying near or slightly east of the present drainage divide. To the SE, ice coalesced to feed a major grounded ice stream in the Moray Firth during ice-sheet deglaciation (Merritt et al., 1995; Bradwell et al., in press). During the Loch Lomond (Younger Dryas) Stadial (12.7 - $11.5 \mathrm{ka}$ cal BP), an icefield formed over the mountains of Assynt and NW Sutherland reaching the northern tip of Loch Shin (Lukas, 2005; Bradwell, 2006).

\section{Methods}

Fields of transverse ridges in the vicinity of Loch Shin (Coir' an Laoigh, Strath Grudie, and Strath Tirry, shown on Fig. 1) were mapped in a spatially attributed ESRI ArcMap GIS using a digital surface model (DSM) with 1.5-m vertical and 5-m horizontal resolution, derived from NEXTMap Britain topographic data. The DSM was illuminated from various directions, limiting the bias introduced by relief-shading and enabling subtle landforms to be identified (cf. Smith and Clark, 2005). Black and white stereoscopic air photos at 1:25,000 scale and georectified colour monoscopic air photos at 1:10,000 scale were also examined to provide further landform detail. Scanned, georectified field maps from early twentieth 
century geological surveys (Geological Survey of Scotland, 1921a, 1921b, 1921c) of the area were consulted in the GIS to aid identification of areas where bedrock lies at, or close to the surface.

Individual ridges were delimited by clear breaks in slope at their bases. Spatial dimensions for twenty randomly selected ridges in each of the fields shown in Fig. 1 were measured in the GIS. Heights and cross profiles were obtained by viewing geometric data extracted from the DSM as profile graphs. For each field of transverse ridges, crest spacing was measured in the GIS along transects parallel to palaeo-ice flow (inferred from regional streamlined landforms and glacial striations). Ridge crest spacing was measured along three regularly spaced transects at Coir' an Laoigh and Strath Tirry. However, only one transect was used at Strath Grudie due to the narrowness of the field.

On the ground, a walk-over survey of each field of transverse ridges was conducted to verify the remote sensing data. Natural sections are small and sparse, but where found sedimentological observations were made, including descriptions of texture, compactness and sedimentary structures. Absence of larger natural sections has precluded in depth sedimentological investigation at this stage.

\section{Results}

The results of the geomorphological mapping are shown in Figs 2, 3, and 4. Each location is described in turn below.

\subsection{Coir' an Laoigh}

Coir' an Laoigh is a shallow valley to the SE of an elevated bedrock outcrop (Figs. 2A, B). The valley continues toward flatter ground at $\sim 180 \mathrm{~m}$ above UK Ordnance Datum (OD), which eventually drops down into the deeper valleys of Glen Cassley to the east and Glen Oykel to the south. A SE trending, 1.5-km-wide field of transverse ridges extends from Coir' an Laoigh across the flatter ground, disappearing on the steeper slopes. The ridges are typically $150-420 \mathrm{~m}$ long, $75-270 \mathrm{~m}$ wide, and $4-12 \mathrm{~m}$ high (Table 1). Many are concave downvalley and possess an asymmetrical cross-profile with gentle upvalley and steeper downvalley slopes (Fig. 5A). Aerial photographs show NW to SE aligned streamlined forms superimposed on some of the ridges (Fig. 2C), particularly toward the southeastern end of the field. Ridge crest spacing is relatively regular for the upper $2 \mathrm{~km}$ of the field, generally between 100 and $300 \mathrm{~m}$ (Fig. 6A). However, downvalley ridge spacing 
becomes much more variable. The longest transect, A2-A2', shows an increase in frequency of ridges $>300 \mathrm{~m}$ apart from $3 \mathrm{~km}$ onwards. Crest spacing in transect A1-A1' increases to > $400 \mathrm{~m}$ from 1.5 to $2.8 \mathrm{~km}$ and then decreases to $<200 \mathrm{~m}$ at $3.5 \mathrm{~km}$ down the field, before increasing to $>600 \mathrm{~m}$ at $4.5 \mathrm{~km}$. Transect A3-A3' shows highly variable crest spacing between 100 and $650 \mathrm{~m}$ from 2.5 to $4.5 \mathrm{~km}$. Natural exposures in the transverse ridges are sparse with small (c. $1 \mathrm{~m}$ ) near-surface sections typically revealing fine sandy, wellconsolidated, matrix-supported diamicton (Fig. 7A). Clasts are generally subrounded, $<1 \mathrm{~m}$ in diameter, and of local lithology. Many are bullet-shaped, faceted and striated.

A separate set of ridges and mounds, some trending obliquely down the valley side, occupy the entrance to Glen Cassley (Fig. 2B). These smaller, more symmetrical (Fig. 5B), boulderscattered ridges are generally $<50 \mathrm{~m}$ wide and $<5 \mathrm{~m}$ in height. They are comprised of poorly sorted diamicton and form arcuate chains that are convex downvalley.

\subsection{Strath Grudie}

Strath Grudie forms a shallow valley, beginning at $\sim 300 \mathrm{~m}$ above OD, immediately SE of an elevated area of bedrock (Figs. 3A, B). It lies on the northeastern periphery of the deeper valley of Glen Cassley, trending parallel to it. A narrow, well defined, 1-km-wide, SE trending field of curved and subparallel, occasionally branching ridges run from the head of the valley down to $\sim 200 \mathrm{~m}$ OD. Typical ridge dimensions are 170 to $560 \mathrm{~m}$ in length, 85 to $205 \mathrm{~m}$ in width and 5 to $15 \mathrm{~m}$ in height (Table 1). Many have steeper downvalley sides and possess broad, flat-topped or rounded crests (Figs. 3C, 5C). Toward the southeastern end of the field, superimposed drumlinoid forms are present. Analysis of ridge crest spacing reveals an overall increase downvalley (Fig. 6B). Along transect B-B' crest spacing is relatively regular at $\sim 100 \mathrm{~m}$ for the first $0.6 \mathrm{~km}$ of the field, then increases to $>200 \mathrm{~m}$ from 0.7 to 1.4 $\mathrm{km}$ before decreasing to $<150 \mathrm{~m}$ from 1.5 to $2.4 \mathrm{~km}$. A sharp increase in ridge crest spacing, up to $500 \mathrm{~m}$, occurs at the SE end of B-B'.

Sparse exposures in ridges at midridge height reveal loose to normally consolidated, massive, sandy, matrix-supported diamicton (Fig. 7B). Clasts are of local lithology, are subrounded to angular, and up to $1.5 \mathrm{~m}$ in diameter. Microfault and shear structures also exist locally. Although a number of streams drain through the area, incisions into the ridges have readily slumped and become revegetated, highlighting the loose nature of some of the sediments. 


\subsection{Strath Tirry}

Forming a flat-bottomed SE trending valley, Strath Tirry begins at $\sim 180 \mathrm{~m} \mathrm{OD}$, to the SE of higher ground (Fig. 4A). It lies on the northeastern margin of the glacially modified broad valley occupied by Loch Shin. The mid and upper sections of Strath Tirry are surrounded by hills up to $290 \mathrm{~m}$ in height. A field of transverse and curved, occasionally branching ridges occupy the upper $6 \mathrm{~km}$ of the valley, gradually trending into a narrow, 1-km-wide corridor of shorter ridges and mounds farther downvalley. Typical ridge lengths range from $445 \mathrm{~m}$ in the upper and middle sections of the valley to $130 \mathrm{~m}$ downvalley. Ridge widths are between 85 and $165 \mathrm{~m}$, while heights are between 5 and $11 \mathrm{~m}$ (Table 1). Many of the Strath Tirry ridges have an asymmetrical cross profile with steeper downvalley slopes (Fig. 5D). Ridge crest spacing generally varies between 100 and $400 \mathrm{~m}$ from 0 to $6 \mathrm{~km}$ down the field, with a notable increase up to $900 \mathrm{~m}$ beyond $6 \mathrm{~km}$ (Fig. 6C). Individually, transect $\mathrm{C} 1-\mathrm{C} 1$ ' shows a slight spacing increase, from 100 to between 200 and $400 \mathrm{~m}$ from 0 to $3 \mathrm{~km}$. Transect C2-C2' reveals an increase in spacing from 100 to $400 \mathrm{~m}$ between 2 and $4 \mathrm{~km}$, followed by a zone of variable spacing, between $\sim 150$ and $500 \mathrm{~m}$, from 4 to $6.5 \mathrm{~km}$. A spacing of $>600 \mathrm{~m}$ separates the final three ridge crests in transect $\mathrm{C} 2-\mathrm{C} 2{ }^{\prime}$. Ridge crest spacing in transect $\mathrm{C} 3-\mathrm{C} 3^{\prime}$ generally varies between 100 and $300 \mathrm{~m}$ from 3.5 to $6.5 \mathrm{~km}$ and then increase to $>550 \mathrm{~m}$ beyond $6.5 \mathrm{~km}$.

Small near surface exposures in flat-topped ridges in upper parts of Strath Tirry reveal loose to moderately well consolidated, massive and crudely stratified, sandy matrix- and clastsupported diamicton. Clasts are generally subangular and of local lithology. Thin, $<10-\mathrm{cm}-$ thick, faulted beds of sorted sands were observed within diamicton near the surface of one ridge.

\section{Interpretation of transverse ridges}

The transverse ridges in Coir' an Laoigh, Strath Grudie, and Strath Tirry form very similar populations, morphometrically distinct from those at the mouth of Glen Cassley (Fig. 8). Hättestrand and Kleman (1999) suggested that individual ribbed (Rogen) moraines are typically 10 - $30 \mathrm{~m}$ high, $150-300 \mathrm{~m}$ wide, and $300-1200 \mathrm{~m}$ long, although Dunlop and Clark (2006) argued that a much greater morphological range exist. Lundqvist (1989) suggests that typical Rogen moraine heights are $10-20 \mathrm{~m}$ and widths are $50-100 \mathrm{~m}$. The Coir' an Laoigh, Strath Grudie, and Strath Tirry transverse ridges are comparable with these values (Table 1). The sinuous or concave downvalley form and the asymmetrical profile of 
many Loch Shin transverse ridges is also consistent with previous observations of ribbed (Rogen) moraine (Hättestrand, 1997). Hättestrand and Kleman (1999) provide examples where individual ribbed (Rogen) moraine ridges appear to fit together like a jig-saw puzzle, although Dunlop and Clark (2006) question this view. Individual ridges in the present study do appear to fit remarkably well in places (Figs. 9A, B), but this is not always the case. The location of the ridges, within 20 - $30 \mathrm{~km}$ of Ballantyne et al.'s (1998) reconstructed ice-sheet divide, is in agreement with previous observations that Rogen moraine often occurs in icesheet core areas (Hättestrand and Kleman, 1999; Kleman and Hättestrand, 1999). The superimposition of drumlinoid forms on lower Coir' an Laoigh (Fig. 2C) and Strath Grudie ridges and the transition of ridges into shorter more equant drumlin-like features in Strath Tirry (Fig. 4B) conforms with one of the key characteristics of classic Rogen moraine, as defined by Lundqvist $(1989,1997)$. As a result, the transverse ridges described in this study are interpreted as Rogen moraine.

The dense, well-consolidated, matrix-supported diamicton within Rogen moraine ridges at Coir' an Laoigh is interpreted as subglacial till, based on its compactness and the presence of striated, bullet-shaped clasts. Sediments in the Strath Grudie moraines may also be interpreted as till; however, their less consolidated nature suggests that the initial mode of deposition may not have been subglacial. Preserved thin beds of sorted sands within diamicton in one Rogen moraine ridge at upper Strath Tirry may indicate that some sediment was deposited by flowing water - small scale faults and deformation structures within these sediments suggest a period of subsequent disruption.

The ridges at the entrance to Glen Cassley, shown in Fig. 2, form an entirely different morphometric population of landforms (Figs. 5 and 8). These lower and narrower ridges are not interpreted as Rogen moraine, but rather ice-marginal moraines deposited by an actively retreating outlet glacier in Glen Cassley.

\section{Formation of Loch Shin Rogen moraine}

In Coir' an Laoigh and Strath Grudie the degree of superimposed drumlinisation appears to increase downvalley. In contrast, Rogen moraine ridges in upper Strath Tirry lack any such superimposed forms. Drumlinisation of Rogen moraine elsewhere is considered to have been a secondary process (Lundqvist, 1997; Möller, 2006; Sarla, 2006) that has modified the original landforms to varying degrees (e.g. Hättestrand and Kleman, 1999). The Rogen moraine ridges in the present study have also likely been influenced to varying degrees by 
post-formation glacial overriding, with little or no modification in upper Strath Tirry to significant modification, for example, in lower Coir' an Laoigh. The question arises, therefore, as to the origin of the ridges prior to this modification.

To reiterate, the four main hypotheses for Rogen moraine formation are: (i) subglacial outburst floods, (ii) modification of preexisting moraines or flutes / drumlins, (iii) shearing and stacking or folding, and (iv) fracturing and extension of existing sediment sheets. We now consider each hypothesis and test them against our data from northern Scotland.

Fisher and Shaw (1992) observed large amounts of sorted and stratified sediment within Rogen moraine ridges on the Avalon Peninsula, Newfoundland. They interpreted the sediment as deposits from hyperconcentrated flows and subaqueous debris flows, and implied formation by infilling of cavities eroded into basal ice by subglacial meltwater. However, subglacial till observed in sections in Coir' an Laoigh demonstrates that sediments within these landforms were not deposited by flowing water. Sorted sands were only observed in one Rogen moraine ridge in upper Strath Tirry, and these occurred as thin $<10 \mathrm{~cm}$ beds, within diamicton. Such sediments would not be expected from high energy water flow capable of eroding large (10 m high) cavities in basal ice (e.g., sorted cobbles, gravels). Landforms indicative of large-scale subglacial drainage events (e.g., rock-cored subglacial meltwater channels, scalloped surfaces and s-forms on bedrock outcrops) have not been observed in or adjacent to any of the Rogen moraine fields in the present study. The Coir' an Laoigh, Strath Grudie and Strath Tirry Rogen moraine fields occur in the lee of elevated ground, but also on the margins of major valleys. Such areas seem unlikely to have experienced focused subglacial sheet flow, sensu Shaw (2002). Furthermore, why internal waves in subglacial sheet flow would have the varying wavelengths seen in the Loch Shin Rogen moraine (Fig. 6), or why they would only occur in the narrow tracks observed in this study (e.g., Strath Grudie, Figs. 3A, B), and produce the branching forms possessed by some ridges (Fig. 8A, B) is difficult to explain. For the above reasons, subglacial outburst floods (hypothesis 1) are considered an unlikely mechanism for the formation of Rogen moraine around Loch Shin in northern Scotland.

With regards to hypothesis 2 , modification of pre-existing landforms is already clear from the superimposed drumlinoid forms. However, Möller (2006) suggested that the pre-existing landforms in Dalarna, central Sweden, were transverse moraine ridges, originally deposited from ice-cored moraines in an ice-marginal zone. Given the relatively subdued topography, and proximity to bedrock, it is questionable whether enough sediment was available to produce such large, closely spaced moraines in the areas occupied by the Loch Shin Rogen 
moraine fields. The ice-marginal moraines in Glen Cassley (Fig. 2, SE corner) despite being located in an area of greater sediment availability, form an entirely different population, distinct from the Rogen moraine ridges (Figures 5 and 8). Marginal moraines comparable in size to the Loch Shin Rogen moraine have been reported elsewhere in Scotland, but these commonly relate to major ice sheet or ice cap still stands forming individual ridges as part of larger ice-marginal assemblages (e.g. Everest and Kubik, 2006; Golledge et al., in 2008). Therefore, it is not likely, based on their size and location, that the original ridges were icemarginal morainic landforms. The Loch Shin area of northern Scotland is characterised by broad glacial valleys draining toward the Moray Firth, which was occupied by an ice sheet outlet lobe on numerous occasions throughout the Quaternary. No evidence exists to suggest that ice flowed perpendicular to these valley axes during a prior glaciation, suggesting that remoulding of pre-existing flutes or drumlins following a $\sim 90^{\circ}$ change in flow direction, sensu Boulton (1987) did not occur. On these grounds, hypothesis 2 is rejected as a potential mechanism by which the Loch Shin Rogen moraine could have formed.

The shearing and stacking or folding mechanism (hypothesis 3) proposes that basal debris is sheared and stacked, or folded during compressive ice flow to form Rogen moraine. Based on extensive sedimentological investigations in northern Sweden, Lindén et al. (2008) presented good evidence for ridge formation through subglacial folding or thrust stacking and lee-side cavity deposition. Bouchard (1989) suggested that compressive flow may occur at topographic obstructions at the down-ice end of rock basins in northern Québec, while Lindén et al. (2008) suggested differences in bed rheology may generate a compressive zone, resulting from a more mobile upglacier bed. However, Rogen moraine in the present study occur down-ice from bedrock obstructions and topographic highs in a zone where ice and sediment thickness increased. Overall extensional flow, rather than compressive flow, is more likely in these locations; and this may be reflected in the observed pattern of generally increasing ridge crest spacing down-ice (Fig 6). However, isolated zones of decreased ridge crest spacing are also present. Dyke et al. (1992) suggested that debris stacking may occur from ice acceleration and deceleration within a patchwork of cold-based ice near the margins of a warm-based ice stream. The observed ridge crest spacing variations may be compatible with formation at the margin of faster flowing ice, with isolated cold-based or low mobility patches occurring in the transitional zone, causing debris stacking.

Hättestrand (1997) suggests that fracturing and extension of existing sediment occurs following a rise in phase change surface (PCS) (approximately equivalent to the pressure melting point isoline) from underlying bedrock into subglacial sediments during a transition from cold- to warm-based conditions during deglaciation (hypothesis 4). This rise in PCS 
creates a top to bottom layering of: ice (deforming), sediments (frozen), and sediments (deforming). Thawing of the bed increases basal ice flow velocity, creating extensional flow which causes brittle failure of the frozen layer into boudins (Hättestrand, 1997). The Loch Shin Rogen moraine occur down-ice from bedrock outcrops and topographic highs in areas likely to have experienced extensional ice flow from increasing basal shear stress. The observed tendency for ridge spacing to increase (Figure 6) may be consistent with a model of fracturing and extension due to strong tensile stresses, under a transitional patchwork of coldto warm-based ice (Hättestrand, 1997, Fig. 8B). The fracturing model (Hättestrand, 1997; Kleman and Hättestrand, 1999) suggests that frozen blocks initially retained high shear strength and remained intact during entrainment. However, subsequent transport into the largely warm-based zone would have lead to down-ice thawing and disaggregation of sediment blocks. The downvalley transformation of ridges into equant, round mounds in the SE end of Strath Tirry (Figs 4A, B) is consistent with this model. Areas of jigsaw matching (Fig 9) lend further support to the fracturing model, particularly in upvalley zones, where transport distances would have been shortest.

A common feature of all the Rogen moraine fields described in this study is their setting, lying down-ice from topographic highs and adjacent to deeper valleys. These areas are extremely likely to have experienced a strong gradient in basal ice-flow velocity, both longitudinally and laterally. Hypothesis 3 (shearing and stacking or folding) and hypothesis 4 (fracturing and extension) both invoke ice-flow velocity changes, and therefore are considered the most likely mechanisms for Rogen moraine formation in the present study. The observation of fault and shear structures may be consistent with either of these mechanisms. However, further work is required to test these hypotheses robustly on sedimentological grounds (cf. Lindén et al., 2008).

Previous studies of Rogen moraine have mainly focused on the role of longitudinal changes in ice-flow velocity in their genesis (e.g. Bouchard, 1989; Hättestrand, 1997; Kleman and Hättestrand, 1999; Lindén et al., 2008). However, we suggest that the narrow form of the Loch Shin Rogen moraine fields (in particular Strath Grudie) indicate that lateral changes in ice flow velocity were also of crucial importance. Our evidence suggests these took place over very short $(1-2 \mathrm{~km}$ ) distances, probably resulting in a subglacial shear margin (Fig. 10). Several of the Strath Grudie Rogen moraine (Figs. 2, 10) are offset in the direction of probable faster ice flow. Within this narrow zone sediment may have been compressed (thrusted) into ridges by more rapidly moving ice flowing alongside less mobile ice, or fractured and extended by less mobile ice becoming entrained within a corridor of rapidly moving ice. The observed tendency for ridge spacing to increase suggests that the latter 
mechanism was more dominant, but areas of ridge clustering indicate that compression and thrusting may also have occurred.

\section{Glaciological Significance}

The clear, distinct morphology of the Rogen moraine identified in this study (e.g., Figs. 2, 3, 4), combined with their locations $\sim 10 \mathrm{~km}$ beyond the maximum limits of Loch Lomond Stadial glaciers (Fig. 1), suggests that they probably formed during a late stage of ice-sheet deglaciation. Their presence strongly suggests that significant basal ice-flow velocity gradients occurred in the vicinity of Loch Shin at that time. Rogen moraine distribution and morphological characteristics within the study area imply that ice flow velocity increased longitudinally and also laterally, with faster, more concentrated flow occurring within the main valleys.

Previous studies have suggested that ribbed (Rogen) moraine may mark the onset of ice streaming (Dyke et al., 1992; Bradwell et al., 2008). The presence of a large palaeo-ice stream in the Moray Firth during the latter stages of ice-sheet deglaciation (17-14 ka BP) was originally proposed by Merritt et al. (1995), based on regional ice-flow patterns in NE Scotland. NEXTMap digital surface models and seabed imagery has confirmed the presence of a large palaeo-ice stream (Bradwell et al., in press), with strongly convergent large-scale glacial lineations on the Black Isle, around the Dornoch Firth, and around Invermoriston west of Loch Ness (J. W. Merritt, British Geological Survey, personal communication, 2007). The influence of the Moray Firth ice stream may have played an additional role in generating strong basal ice-flow velocity gradients required for Rogen moraine formation. Here, inland ice would have increasingly contributed to the Moray Firth ice stream in an area of convergent ice flow, akin to an ice stream onset zone (e.g. Stokes and Clark, 2001; Bradwell et al., 2008; Kleman and Glasser, 2007). Interpreted in this way, the landforms could be consistent with formation during headward ice stream scavenging into a shrinking core of cold-based ice.

The Rogen moraine described here are best explained by separation and extension of existing sediment or thrusting and stacking in areas characterised by strong basal ice flow velocity gradients. However, evidence exists in different geographical areas for other mechanisms of formation (e.g., Boulton, 1987; Möller, 2006). Therefore, the mechanisms favoured here may be considered one means by which an essentially polygenetic group of landforms, known as Rogen moraine, are formed. 


\section{Conclusions}

Our main conclusions from this work are as follows:

i. NEXTMap digital surface models, in combination with field mapping, have revealed several linear zones of transverse ridges, some with superimposed drumlinoid elements in the vicinity of Loch Shin, northern Scotland.

ii. Individual ridges in Coir' an Laoigh, Strath Grudie, and Strath Tirry range in width from 75 to $264 \mathrm{~m}$, in length from 132 to $561 \mathrm{~m}$, and in height from 4 to $15 \mathrm{~m}$. Interridge spacing ranges from 80 to $878 \mathrm{~m}$, with an overall tendency to increase in a down-ice direction.

iii. Based on their characteristic shape, size, topographic setting and geographical distribution, we interpret these groups of ridges to be fields of Rogen moraine.

iv. Common to all Rogen moraine fields is their location in areas that would have experienced strong, longitudinal or lateral basal ice flow velocity gradients. Sediment thrusting by compression, or fracturing by extension is likely to have occurred in these areas, forming the Rogen moraine. An overall increase in ridge spacing suggests that the latter was more dominant.

v. Headward ice stream scavenging, during ice-sheet deglaciation, could have played an additional role in generating velocity gradients necessary for Rogen moraine formation.

\section{Acknowledgements}

We are grateful to BGS colleagues Nick Golledge, Chris Thomas, Jon Merritt and Jez Everest for discussions concerning these landforms. The constructive reviews of two anonymous referees greatly improved this manuscript. This paper is published with the permission of the Executive Director of BGS (NERC). 


\section{References}

Aylsworth, J.M., Shilts, W.W., 1989. Bedforms of the Keewatin Ice Sheet, Canada. Sedimentary Geology 62, 407-428.

Ballantyne, C.K., McCarroll, D., Nesje, A., Olaf Dahl, S., Stone, J.O., 1998. The last ice sheet in north-west Scotland: reconstruction and implications. Quaternary Science Reviews 17, 1149-1184.

Bouchard, M., 1989. Subglacial landforms and deposits in central and northern Quebec, Canada, with emphasis on Rogen moraines. Sedimentary Geology 62, 239-308.

Boulton, G.S., 1987. A theory of drumlin formation by subglacial deformation. In: Menzies, J., Rose, J. (Eds), Drumlin Symposium. Balkema, Rotterdam, The Netherlands, pp. 25-80.

Bradwell, T. 2006., The Loch Lomond Stadial glaciation in Assynt: a reappraisal. Scottish Geographical Journal 122, 274-292.

Bradwell, T., Stoker, M., Krabbendam, M., 2008. Megagrooves and streamlined bedrock in NW Scotland: the role of ice streams in landscape evolution. Geomorphology doi:10.1016/j.geomorph.2007.02.046.

Bradwell, T., Stoker, M., Golledge, N.R., Merritt, J.W., Long, D., Everest, J., Hestvik, O.B., Hubbard, A., Finlayson, A.G. and Mathers, H., in press. The northern sector of last British Ice Sheet: maximum extent and demise. Earth Science Reviews.

Clark, C.D., Meehan, R., 2001. Subglacial bedform geomorphology of the Irish Ice Sheet reveals major configuration changes during growth and decay. Journal of Quaternary Science $16,483-496$.

Cowan, W.R., 1968. Ribbed moraine: till fabric analysis and origin. Canadian Journal of Earth Sciences 5, 1145-1159.

Dyke, A.S., Morris, T.F., Green, D.E.C., England, J., 1992. Quaternary geology of Prince of Wales Island, Arctic Canada. Geological Survey of Canada Memoir 433, 142.

Dunlop, P., Clark, C.D., 2006. The morphological characteristics of ribbed moraine. Quaternary Science reviews 25, 1668-1691.

Everest, J.D., Kubik, P., 2006. The deglaciation of eastern Scotland: cosmogenic ${ }^{10} \mathrm{Be}$ evidence for a Lateglacial stillstand. Journal of Quaternary Science 21, 95-104.

Finlayson, A.G., Bradwell, T., 2007. Evidence for a Younger Dryas ice cap glaciation of the Beinn Dearg Massif, northern Scotland. Quaternary Newsletter 113, 10-17..

Fisher, T.G., Shaw, J. 1992., A depositional model for Rogen moraine, with examples from the Avalon Peninsula, Newfoundland. Canadian Journal of Earth Sciences 29, 669-686. 
Frödin, G., 1925. Studien über die Eissheide in Zentralskandinavien. Bulletin of the Geological Institutions at the University of Upsala, Sweden 19, 214 pp.

Geological Survey of Scotland, 1921a. Sutherland county sheet 85. Clean copy. HMSO.

Geological Survey of Scotland, 1921b. Sutherland county sheet 93. Clean copy. HMSO.

Geological Survey of Scotland, 1921c. Sutherland county sheet 101. Clean copy. HMSO.

Golledge, N.R., 2006. The Loch Lomond Stadial glaciation south of Rannoch Moor: new evidence and palaeoglaciological insights. Scottish Geographical Journal, 122, 326-343.

Golledge, N.R., Merritt, J.W., 2005. Evidence for the sequence of glacial events in the Solway Lowlands from a new 5-m-resolution DTM. Book of Abstracts, International Conference on Glacial Sedimentary Processes and Products, Aberystwyth, UK.

Golledge, N.R., Finlayson, A.G., Bradwell, T., Everest, J.D., 2008. The last glaciation of Shetland: new insights from a landsystems approach. Geografiska Annaler, 90 (A), 37-53.

Hättestrand, C., 1997. Ribbed moraines in Sweden - distribution, pattern and palaeoglaciological implications. Sedimentary Geology 111, 41-56.

Hättestrand, C., Kleman, J., 1999. Ribbed moraine formation. Quaternary Science Reviews $18,43-61$.

Hughes, O.L., 1964. Surficial Geology, Nichicun-Kaniapiskau map-area, Quebec. Geological Survey of Canada Bulletin 106.

Kleman, J., Hättestrand, C., 1999. Frozen-bed Fennoscandian and Laurentide ice sheets during the Last Glacial Maximum. Nature 402, 63-66.

Kleman, J., Glasser, N.F., 2007. The subglacial thermal organisation of ice sheets. Quaternary Science Reviews 26, 585-597.

Knight, J., McCabe, A.M., 1997. Identification and significance of ice-flow transverse subglacial ridges (Rogen moraines) in north central Ireland. Journal of Quaternary Science 12, 519-534.

Lindén, M., Möller, P., Adrielsson, L., 2008. Ribbed moraine formed by subglacial folding, thrust stacking and lee-side cavity fill. Boreas 37, 102-131.

Lukas, S., 2005. Younger Dryas moraines in the NW Highlands of Scotland: genesis, significance and potential modern analogues. Unpublished $\mathrm{PhD}$ thesis, University of $\mathrm{St}$ Andrews, Scotland.

Lundqvist, J. 1969. Problems of the So-called Rogen Moraine. Swedish Geological Survey Series C, 648, 32 pp.

Lundqvist, J., 1989. Rogen (ribbed) moraine: identification and possible origin. Sedimentary Geology 62, 281-292.

Lundqvist, J. 1997. Rogen moraine - an example of two-step formation of glacial landscapes. Sedimentary Geology, 111, 27-40. 
Merritt, J.W., Auton, C.A., Firth, C.R., 1995. Ice-proximal glaciomarine sedimentation and sea-level change in the Inverness area, Scotland - a review of the deglaciation of a major ice stream of the British late Devensian ice-sheet. Quaternary Science Reviews 14, 289-329.

Möller, P,. 2006. Rogen moraine: an example of glacial re-shaping of pre-existing landforms. Quaternary Science Reviews 25, 362-389.

Raunholm, S., Serjup, H.P., Larsen, E., 2003. Lateglacial landform associations at Jæren (SW Norway) and their glaci-dynamic implications. Boreas 32, 462-475.

Sarla, P., 2006. Ribbed moraine stratigraphy and formation in southern Finnish Lapland. Journal of Quaternary Science 21, 387-398.

Shaw, J., 1979. Genesis of the Sveg tills and Rogen moraines of central Sweden: a model of basal melt-out. Boreas 8, 409-426.

Shaw, J., 2002. The meltwater hypothesis for subglacial bedforms. Quaternary International 90, 5-22.

Sissons, J.B., 1977. The Loch Lomond Readvance in the Northern Mainland of Scotland. In Gray, J.M., Lowe, J.J. (Eds) Studies in the Scottish Lateglacial environment. Pergamon, Oxford, 45-59.

Sollid, J.L., Sørbel, L., 1994. Distribution of glacial landforms in southern Norway in relation to the thermal regime of the last continental ice sheet. Geografiska Annaler 76A, 25-35.

Stokes, C.R., Clark, C.D., 2001. Palaeo-ice streams. Quaternary Science Reviews 20, 14371457.

Stokes, C.R., Clark, C.D., Lian, O., Tulaczyk, S., 2006. Geomorphological map of ribbed moraine on the Dubawnt Lake Ice Stream bed: a signature of ice stream shut-down? Journal of Maps 1-9. 


\section{Figure Captions}

Fig 1. Location of Rogen moraine fields in the Loch Shin area. Boxed areas give the location of study sites shown in Figs. 2, 3, and 4. Approximate Last Glacial Maximum (LGM) ice divide as suggested by Ballantyne et al. (1998); limit of Loch Lomond Stadial glaciation taken from Sissons (1977), Lukas (2005), Bradwell (2006), and Finlayson and Bradwell (2007). Inset shows location in Scotland.

Fig 2. (A) Hill-shaded digital surface model, built from Intermap Technologies NEXTMap Britain topographic data, showing transverse ridges in Coir' an Laoigh. Illumination from NW. (B) Geomorphological map of the Coir' an Laoigh area. Contours at $10 \mathrm{~m}$ intervals. (C) Black and white aerial photograph showing development superimposed streamlined landforms in the SE (bottom right).

Fig 3. (A) Hill-shaded digital surface model, built from Intermap Technologies NEXTMap Britain topographic data, showing transverse ridges at Strath Grudie. Illumination from NW.

(B) Geomorphological map of the Strath Grudie area. Contours at $10 \mathrm{~m}$ intervals. (C) Photograph showing asymmetrical, flat-topped cross profile of a transverse ridge in Strath Grudie. Note how the stream incision has readily slumped and become revegetated.

Fig 4. (A) Geomorphological map of the Strath Tirry area. Contours at $10 \mathrm{~m}$ intervals. (B) Oblique hill-shaded digital surface model, built from Intermap Technologies NEXTMap Britain topographic data, showing downvalley increase in spacing and rounding of ridges Illumination from NW. View is from point $\mathbf{X}$ in Figure 4A to west. Vertical exaggeration $\mathbf{x}$ 5.

Fig 5. Cross profiles for ridges from Coir' an Laoigh (A), Glen Cassley (B), Strath Grudie (C), and Strath Tirry (D) derived from digital surface model.

Fig 6. Ridge crest spacing plotted against distance down transect for Coir' an Laoigh (A), Strath Grudie (B), and Strath Tirry (C). 
Fig 7. (A) Exposure of well-consolidated, fine sandy, matrix supported diamicton in transverse ridges in Coir' an Laoigh. (B) Exposure of loose, massive, sandy, matrixsupported diamicton in transverse ridge at Strath Grudie.

Fig 8. Dimensions of sample ridge populations from Coir' an Laoigh, Strath Grudie, Strath Tirry, and Glen Cassley, shown as cumulative percentages of total number of ridges. The steps at $\sim 20$ percent on the Strath Grudie and Strath Tirry ridge length curves are due to downvalley variations, with slightly longer ridges occurring in the middle and lower sections of Strath Grudie, and middle sections of Strath Tirry. The step at 5 percent on the Coir' an Laoigh ridge width curve is due to the wide ridge at the eastern end of that field (Fig. 2).

Fig 9. Exaples of jigsaw matching of transverse ridges from upper Strath Grudie (A) and upper Strath Tirry (B). Hill-shaded digital surface model, built from Intermap Technologies NEXTMap Britain topographic data. Illumination from NW.

Fig 10. Oblique hill-shaded digital surface model, built from Intermap Technologies NEXTMap Britain topographic data, illustrating narrow track of Rogen moraine occupying a probable zone of strong former lateral basal ice-flow velocity gradient (subglacial shear margin). Black arrows denote relative basal ice flow velocity. Note the slight offset of Rogen moraine in the direction of inferred faster ice flow.

\section{Table Captions}

Table 1. Dimensions of Loch Shin Rogen moraines and ribbed moraines reported in Dunlop and Clark (2006) and Hättestrand and Kleman (1999). 


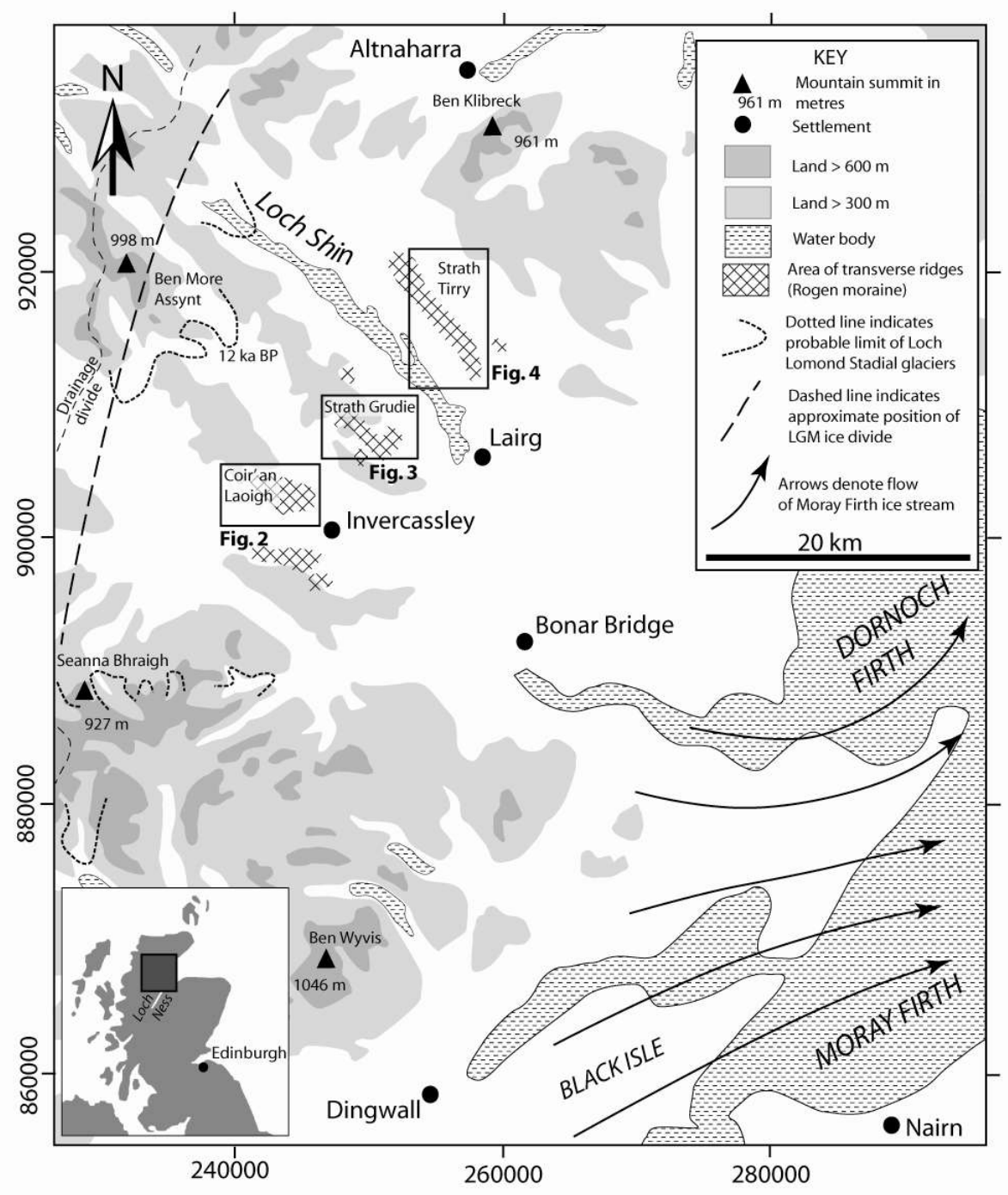

Figure 1. 

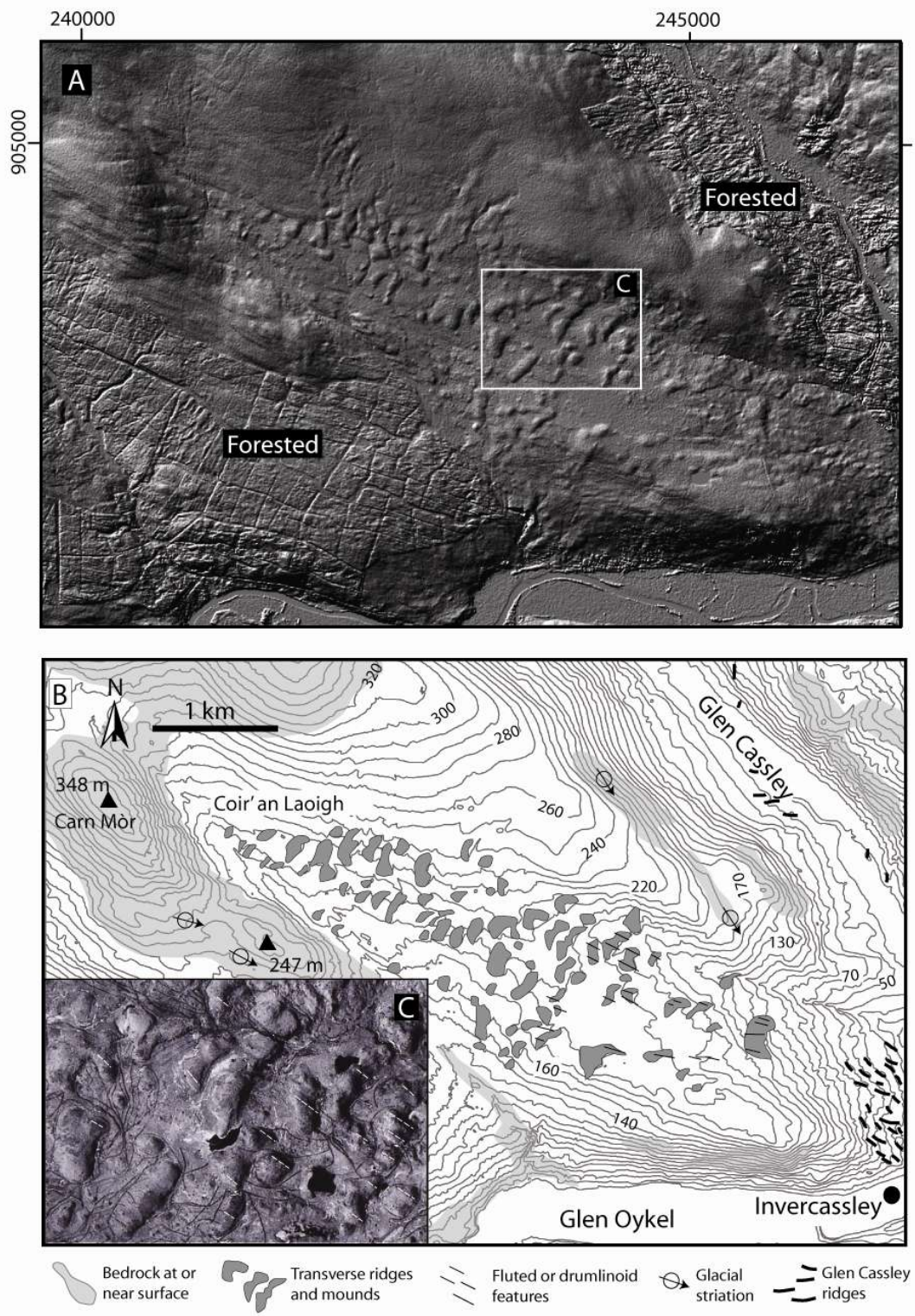

Figure 2. 

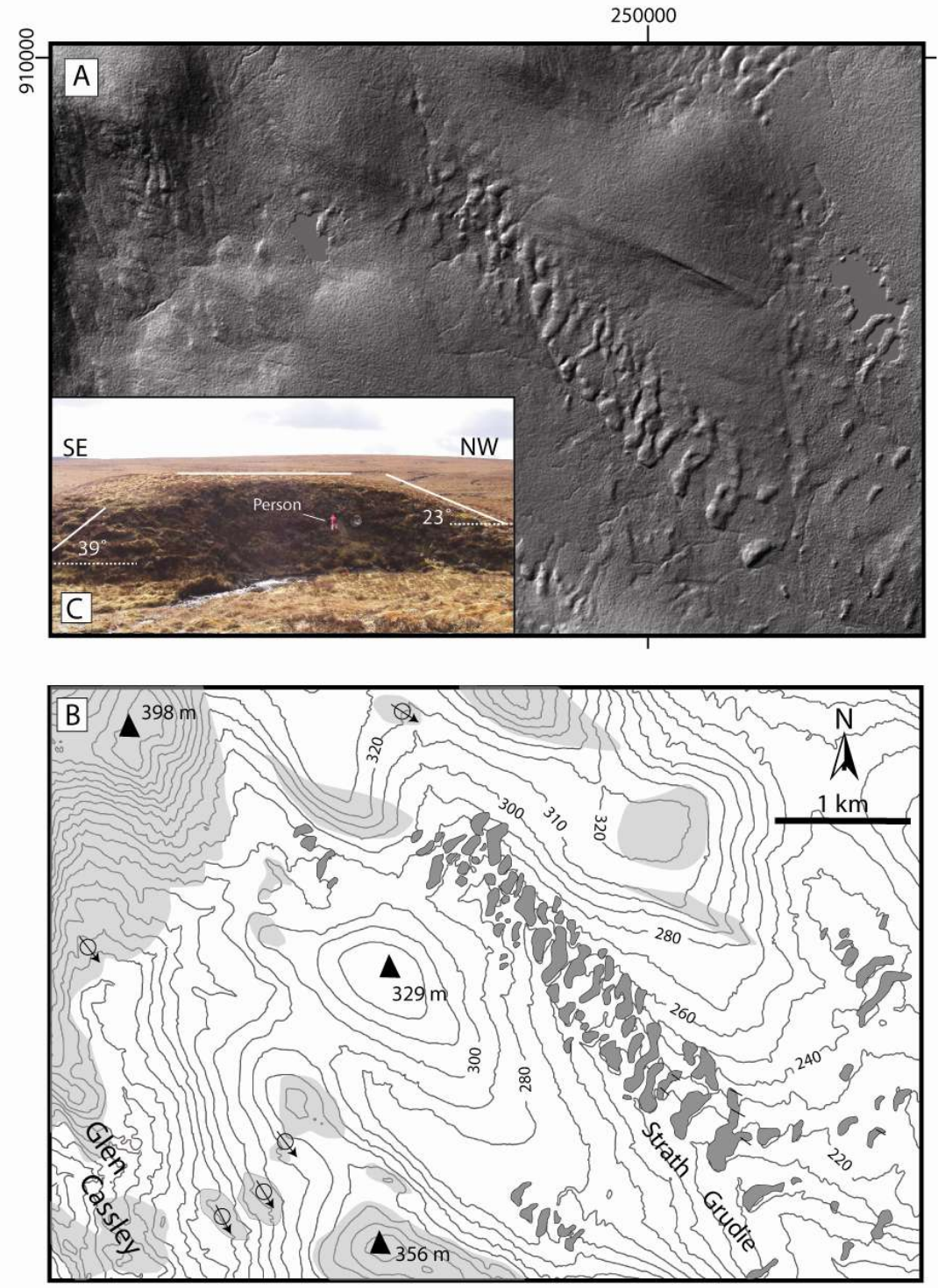

Figure 3. 

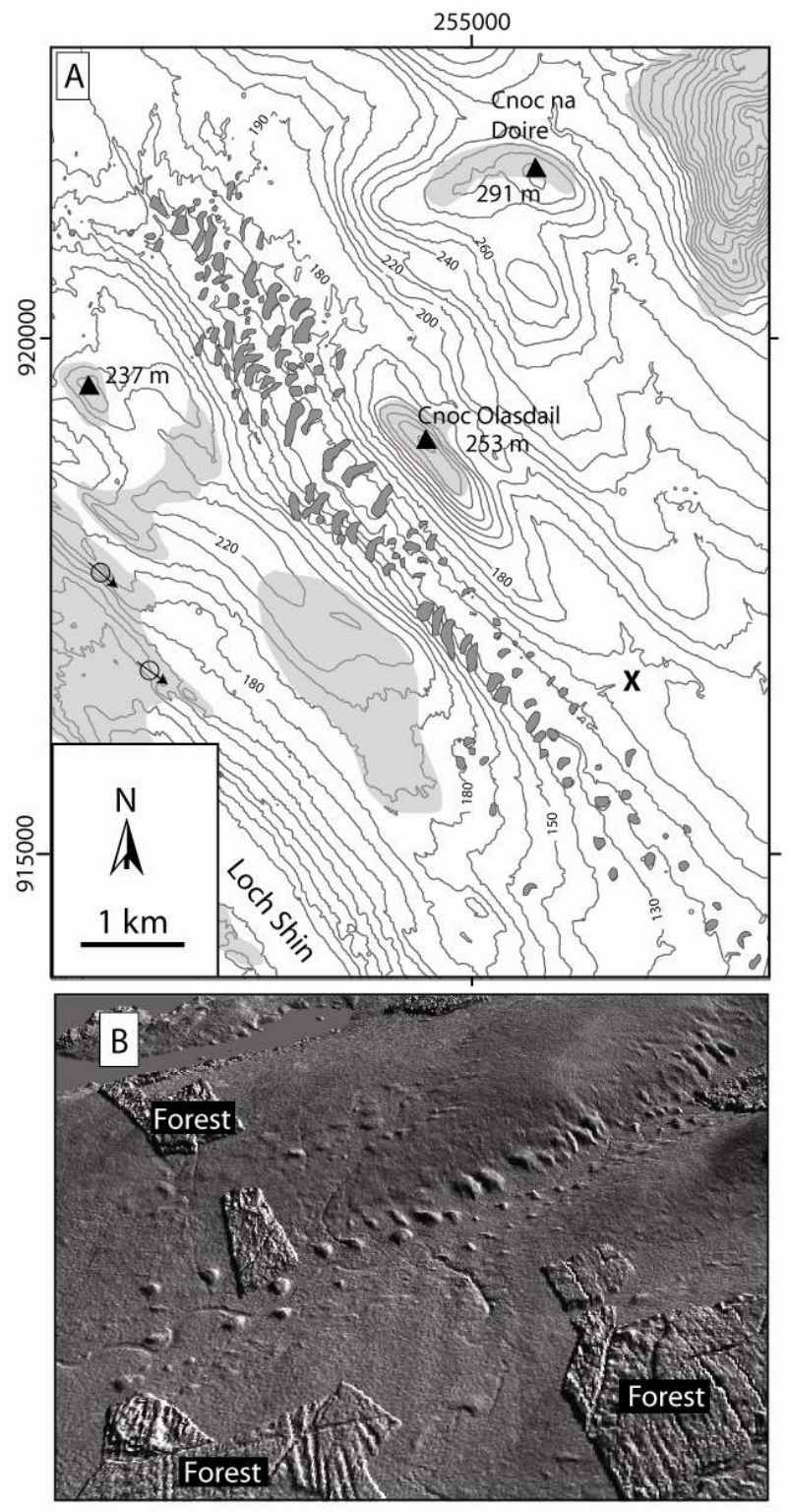

Figure 4. 
A
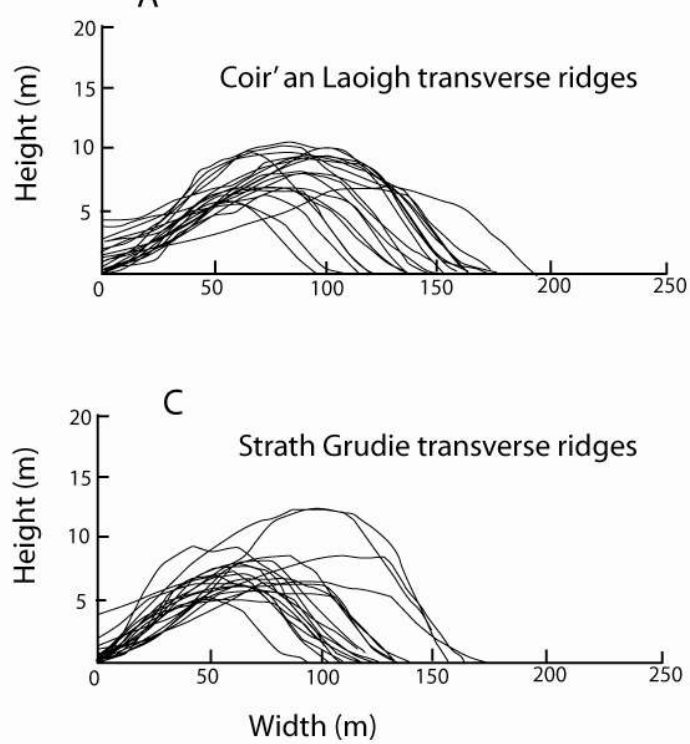

B

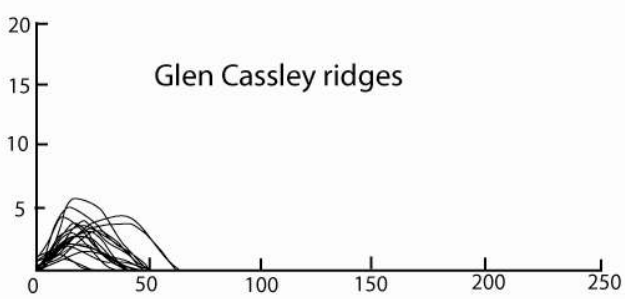

D

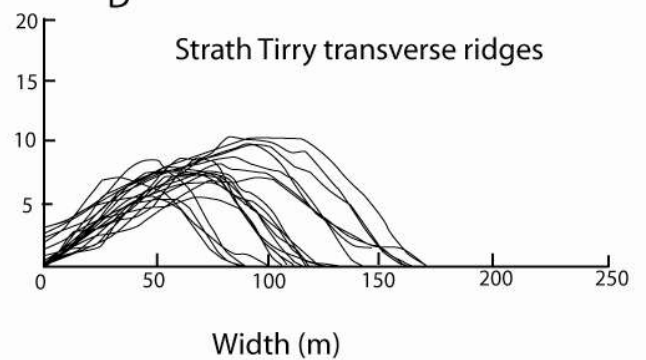

Figure 5. 

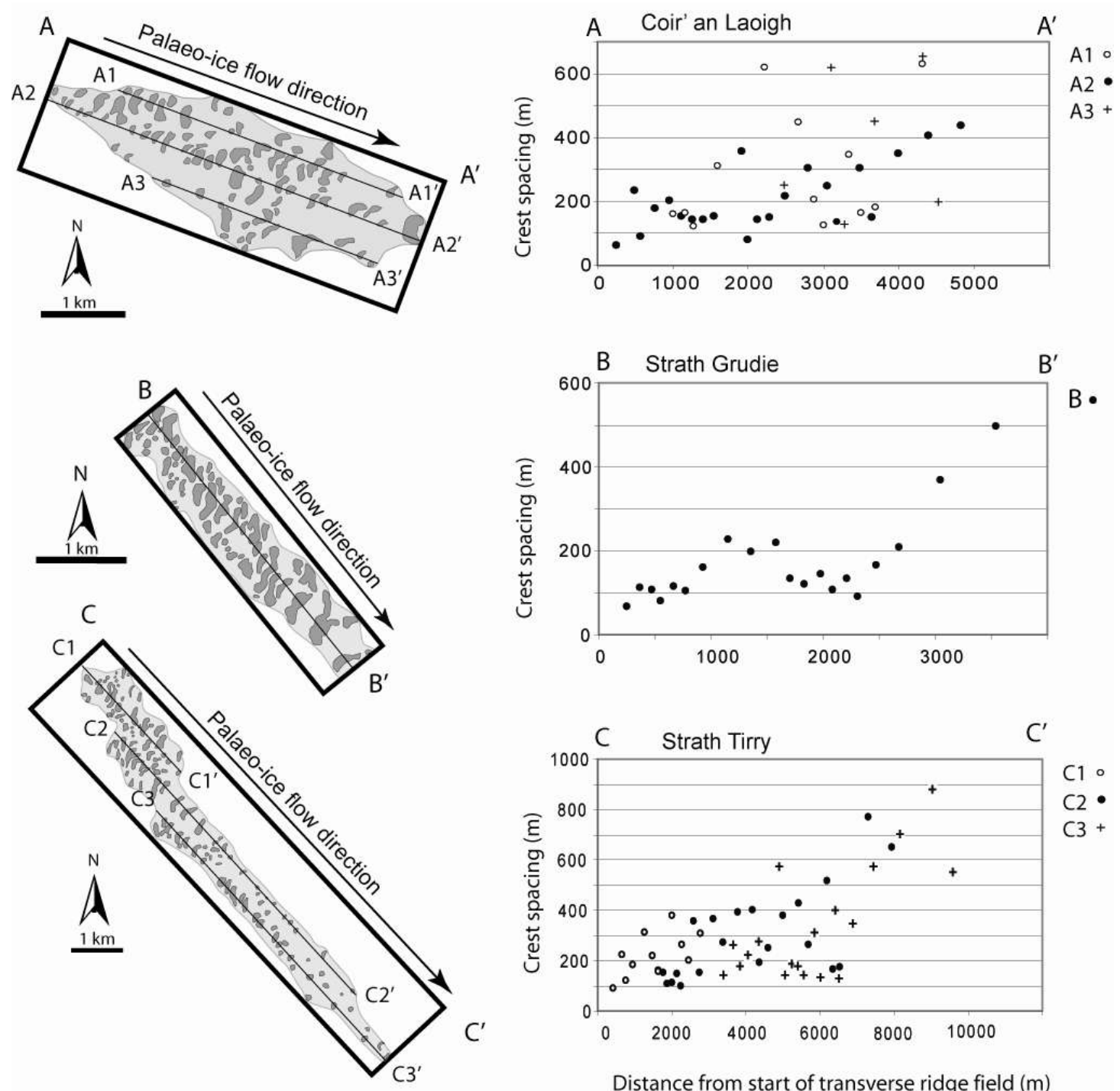

Figure 6.

Distance from start of transverse ridge field $(\mathrm{m})$ 


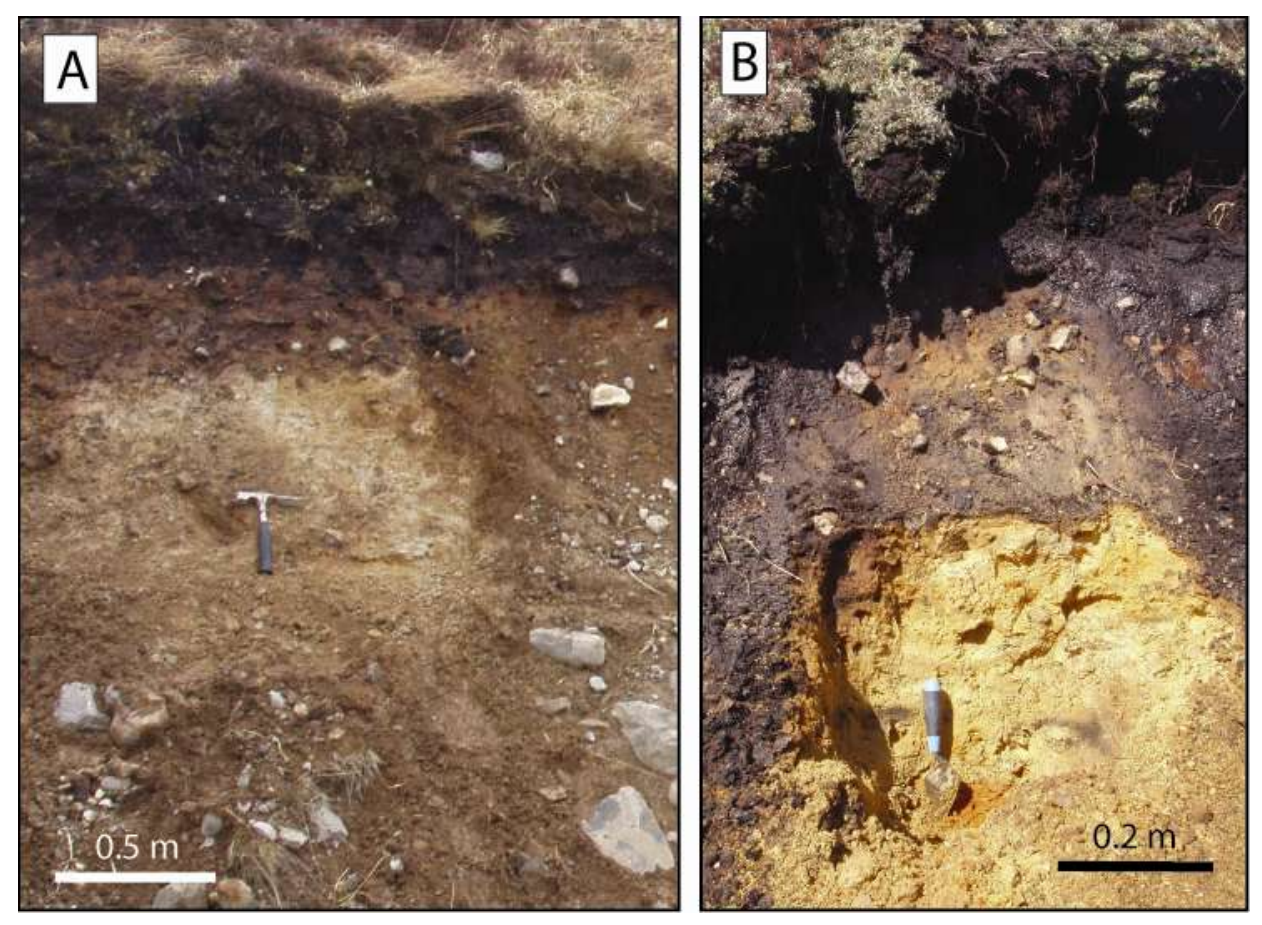

Figure 7. 

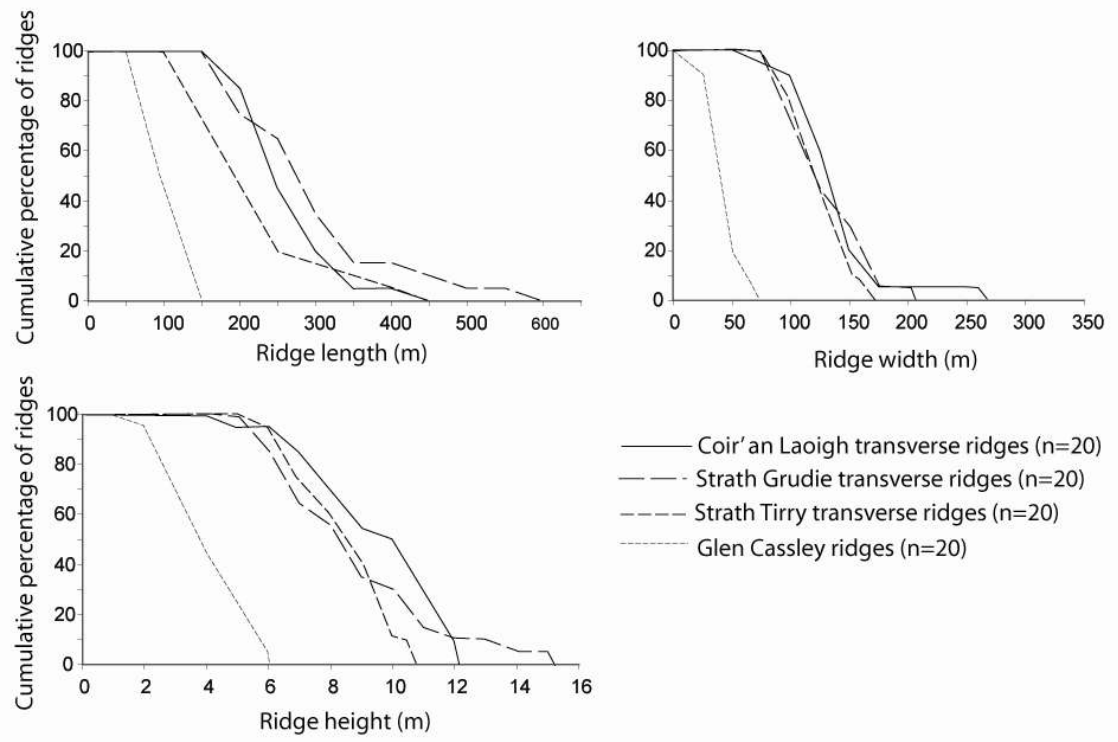

Coir' an Laoigh transverse ridges $(n=20)$

- - Strath Grudie transverse ridges $(n=20)$

- - - Strath Tirry transverse ridges $(n=20)$

Glen Cassley ridges $(n=20)$

Figure 8. 

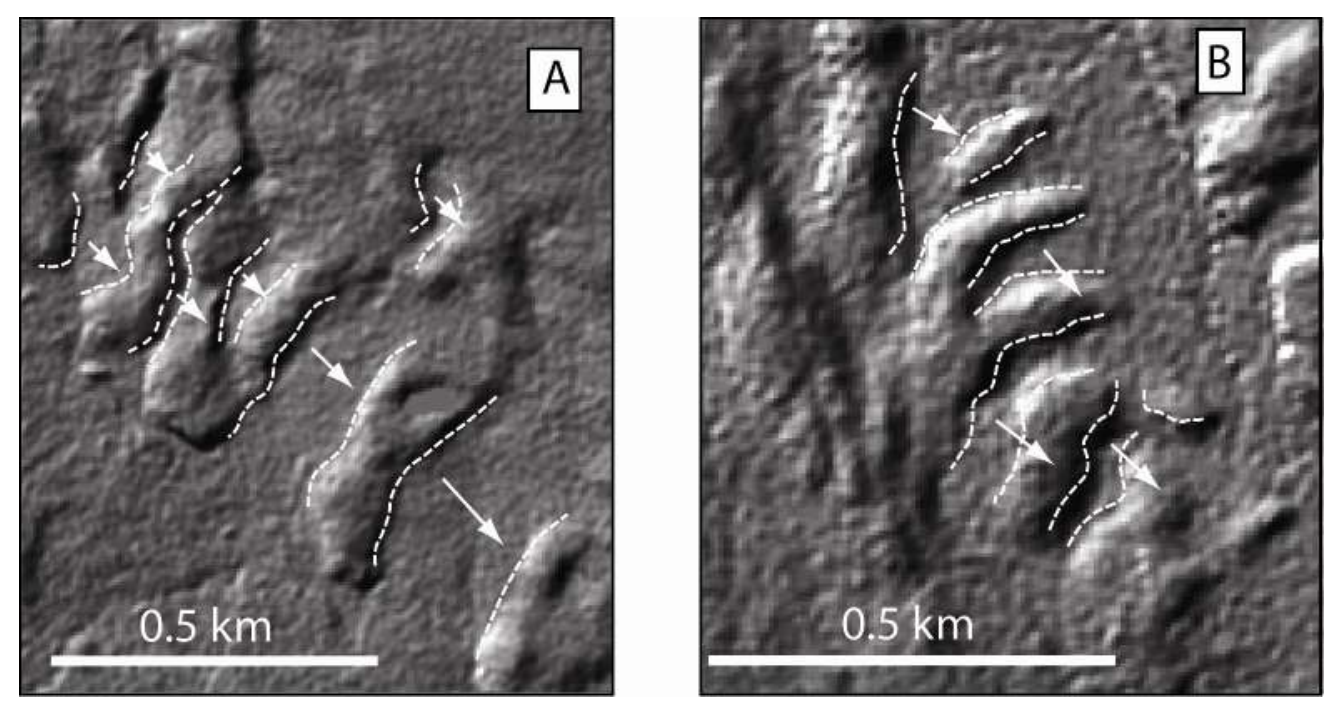

Figure 9.

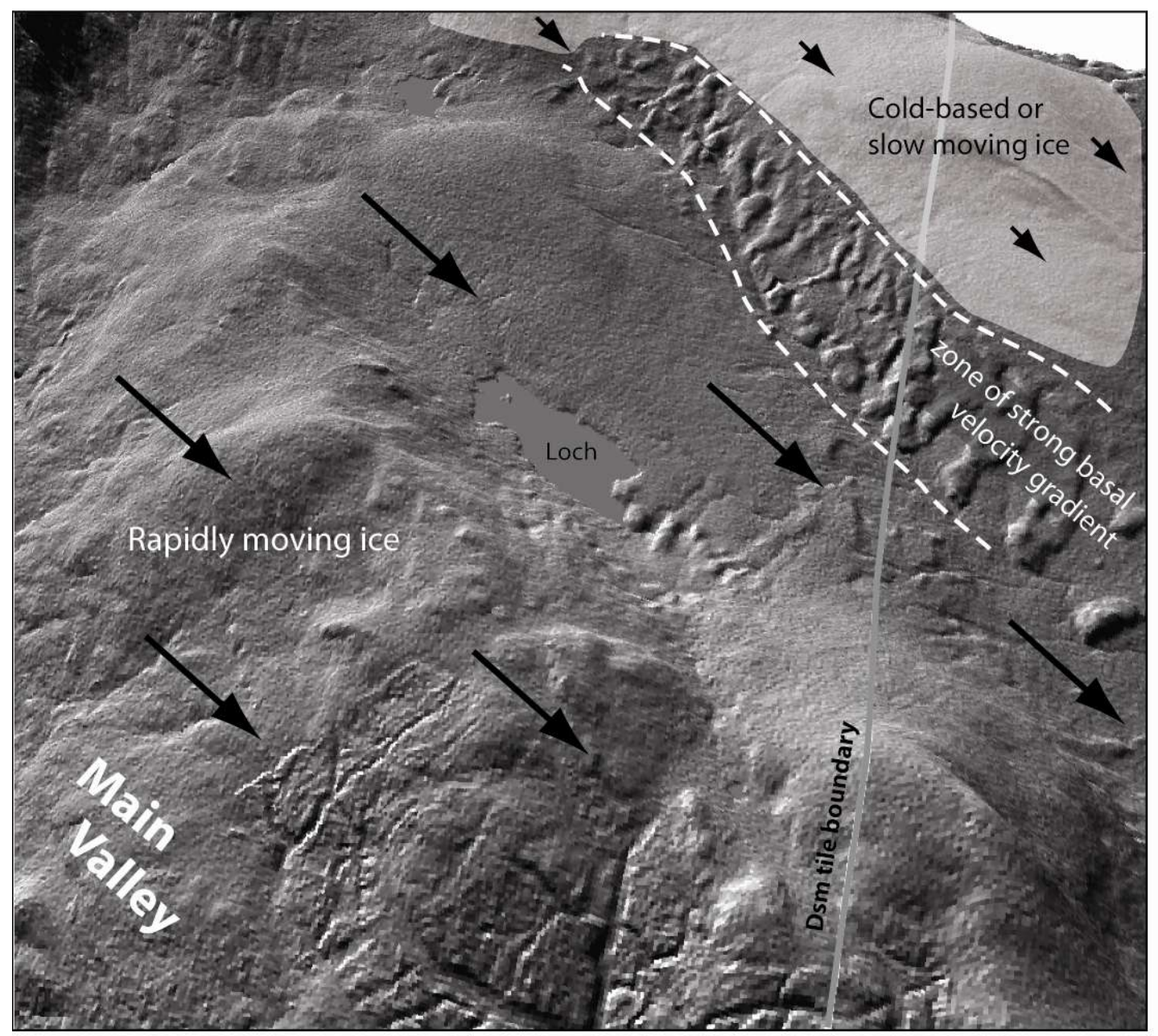

Figure 10. 


\begin{tabular}{|c|c|c|c|c|c|c|c|c|c|c|}
\hline \multirow{3}{*}{$\begin{array}{l}\text { Paramet } \\
\text { er } \\
\text { (m) }\end{array}$} & \multicolumn{6}{|l|}{ Area } & \multirow{3}{*}{$\begin{array}{l}\text { All Loch } \\
\text { Shin } \\
\text { transverse } \\
\text { ridges } \\
\text { Mean } \\
\end{array}$} & \multirow{2}{*}{\multicolumn{2}{|c|}{$\begin{array}{l}\text { Dimensions } \\
\text { reported in } \\
\text { Dunlop and } \\
\text { Clark (2006) }\end{array}$}} & \multirow{3}{*}{$\begin{array}{l}\text { Dimensions } \\
\text { reported in } \\
\text { Hättestrand } \\
\text { and Kleman } \\
(1999) \\
\text { Range }\end{array}$} \\
\hline & \multicolumn{2}{|c|}{$\begin{array}{l}\text { Coir' an Laoigh } \\
\mathrm{n}=20\end{array}$} & \multicolumn{2}{|c|}{$\begin{array}{l}\text { Strath Grudie } \\
\mathrm{n}=20\end{array}$} & \multicolumn{2}{|c|}{$\begin{array}{l}\text { Strath Tirry } \\
\mathrm{n}=20\end{array}$} & & & & \\
\hline & Range & Mean & Range & Mean & Range & Mean & & Range & Mean & \\
\hline Length & $158-414$ & 259 & $169-561$ & 292 & $132-442$ & 212 & 254 & $45-16214$ & 688 & $300-1200$ \\
\hline Width & $75-264$ & 137 & $85-204$ & 128 & $88-164$ & 121 & 129 & $17-1116$ & 278 & $150-300$ \\
\hline Height & $4-12$ & 9 & $5-15$ & 8 & $5-11$ & 8 & 8 & $1-64$ & 17 & $10-30$ \\
\hline Wavelength & $84-411$ & 191 & $80-500$ & 168 & $94-878$ & 281 & 223 & $12-5800$ & 505 & \\
\hline
\end{tabular}

Table 1. Dimensions of Loch Shin Rogen moraine and ribbed moraine reported in Dunlop and Clark (2006) and Hättestrand and Kleman (1999). 